\title{
Socio-Economic and Parental Attention toward Learning Achievement with Mediation of Motivation to Learn
}

\author{
Saidun Hutasuhut*, Indah Putri Wirawan
}

Faculty of Economics, Universitas Negeri Medan, Indonesia

\section{Article History: \\ Received: April 25 $5^{\text {th }}, 2019$ \\ Revised: June $3^{\text {rd }}, 2019$ \\ Accepted: November 22 $2^{\text {nd }}, 2019$ \\ Published: December 27 2019}

\section{$\overline{\text { Keywords: }}$}

Achievement,

Motivation to learn,

Parental attention,

Socio-economic

*Correspondence Address: saidun@unimed.ac.id

\begin{abstract}
This study investigates the influence of parents' socioeconomic conditions and attention to motivation to learn and learning achievement, moreover, also examine the mediation of motivation to learn on the influence of socio-economic conditions and parents' attention toward learning achievement. This study uses the ex-postfacto method. The data collection used in this study was questionnaires. The study population was eighth-grade students of junior high school in Medan, Indonesia, as many as 213 people and the samples taken were 138 people. The data analysis technique uses here as path analysis. The findings in the study are the socioeconomic conditions and parents' attention directly, positively and significantly influence students' motivation to learn. Then the parents' socio-economic conditions, parents' attention, and motivation to learn have a positive and significant direct effect on learning achievement. Furthermore, motivation to learn is considered to mediate the influence of socio-economic conditions and parents' attention to social studies learning achievement. Parents' attention also mediates the influence of parents' socio-economic conditions on motivation to learn and learning achievement. Learning achievement is more accessible to achieve for families with adequately socio-economic conditions. Social studies learning achievements can be improved by increasing the attention of parents because it will increase motivation and further improve learning achievement.
\end{abstract}

\section{INTRODUCTION}

One of the subjects taught in junior high school today is Social Studies (known as Ilmu Pengetahuan Sosial or IPS in Indonesia). Social Studies has an essential task for the intellectual, emotional, cultural, and social development of students, namely being able to develop responsible ways of thinking, behaving, and behaving as individuals, citizens, and citizens of the world (Maryani \& Syamsudin, 2009). The purpose and essence of social studies learning must be able to prepare, foster, and shape the ability of students who master the knowledge, attitudes, values and basic skills needed for life in society (Yuliati, 2009).

Social studies subjects are a combination of several fields of social studies such as sociology, history, geography, economics, politics, law, and culture (Maryani \& Syamsudin, 2009). So that social studies learning must be done in an integrated manner. The complexity of the knowledge taught in social studies makes many students feel that this subject is too difficult to understand. Many students complain and lack attention while studying this subject. When the 
author tested the problem (instrument) on students of state junior high school in Medan there were $70.51 \%$ of students obtained a standard below the Minimum Completion Criteria (MCC) 70 and 29.49 $\%$ were above the MCC. The condition is almost the same that happened in state junior high school in Yogyakarta. Social studies learning outcomes of superior classes are below $100 \%$, which reaches MCC 75, and in non-superior classes, less than $50 \%$ reach MCC (Utami \& Gafur, 2015). Then the ability to study social studies SMP PGRI 16 Brangsong Kendal Regency is not much different. Class VIII students who complete the MCC score are only $30 \%$ and those who do not complete the MCC are $70 \%$ (W. W. Astuti, FX, \& Partono, 2012). This situation needs to be overcome by knowing what factors can improve social studies learning outcomes.

Seven factors cause students difficulties in learning social studies subjects, namely (1) learning facilities and infrastructure at home; (2) school support; (3) family support; (4) student interest; (5) student attention; (6) physical condition of students; (7) teacher (DWP \& Sulistyowati, 2006). Three outlines are seen in the causal factors of students' social studies learning difficulties, namely factors from the students themselves, factors from parents, and factors from school. In social studies learning, not all schools can provide appropriate media and means of supporting social studies learning. Besides that, the teacher's ability to teach social studies is also not necessarily maximal.

Another factor that influences student learning achievement is the role of parents reflected in the fulfillment of facilities and infrastructure at-home learning, attention, and support from the family. Parents have a critical role and role models at home. Although the child has been entrusted at school, parents still play an essential role in children's learning achievement (Umar, 2015). Furthermore, parents act as the first educator in the family towards children (S. P. Astuti \& Handayani, 2017). Parents play an essential role in determining children's development because parents have strong inner bonds for children. Parents also play a role in characterizing children. Children begin to learn and imitate what they see, especially the behavior of parents because family is one of the forms of a child's character. Care for families is very important for children's development (Rakhmawati, 2015).

Parental support in meeting the learning facilities and infrastructure needed by children depends on the socioeconomic conditions of the parents. Socio-economic status is illustrated by the size of income received by a person, the level of education, and the position in his occupation (Rahardjo \& Firdaus, 2015). Then the socio-economic status is a combination of social status and economic conditions in the community (Afiati \& Kurniawan, 2014). Parents who have high socio-economic conditions will certainly provide facilities, facilities, and a pleasant learning environment for children so that children can learn well and can improve their learning achievement. Even further, children will be able to reach their dreams more easily. High socio-economic status of parents will also influence the continuing education of their children, and it cannot be denied that the cost of education is quite high (Haq \& Setiyani, 2016). The low economic condition of parents will have difficulty in fulfilling the cost of education so that it has an impact on the continuity of children's education.

The parents' socio-economic conditions also influence the pattern of educating children. Households are the places where children are educated and raised, and it influences the growth and development of children. Then the level of education possessed by parents has a significant influence on the mystical atmosphere of children, especially in the 
child's personality and education (Ahmadi, 2005). However, to meet these needs, parents often experience problems, especially for parents who are in the sphere of socio-economic conditions of low parents. Parents with low socioeconomic conditions tend not to be able to provide suitable learning facilities for their children, so learning achievements will also be disrupted.

In everyday life, parents with low socio-economic conditions often encountered. They tend to direct children to master the subjects that have a direct effect on family economic life, such as Mathematics, English, or other exact subjects. They become less care in social subjects such as social studies, arts, and culture, language, religion, civic education, and non-exact subjects. However, every parent has the same expectations for their children. Although their socio-economic conditions are different, good parents will continue to try their best to be able to send their children to school and provide the best education for their children as a form of support for the future of their children.

In reality, not all children who come from well-off parents have a significant influence on students' learning achievement. Parents as the first social environment known to students and family figures that are first known to students are their parents; therefore, the support and attention of parents is a considerable influence on the development of students (S. P. Astuti \& Handayani, 2017). Parental attention is a factor that is needed by students to develop well. Excellent and proper attention from parents will certainly move students' feelings in improving their learning achievement.

The form of parental attention to children can be in the form of giving guidance and advice; fulfilling psychological needs such as exemplary motivation and communication, providing learning facilities, and supervision will help improve student learning achievement (Palupi \& Djazari, 2017). Then, according to (Djamarah, Bahri, \& Zain, 2010) giving parents attention in children's learning can be done through; (a) giving awards/prizes; (b) giving punishment; (c) give an example; (d) providing learning facilities, and (e) assist children's learning activities. Parental attention will lead to motivation in him to become a better person. Further parental support influences academic achievement (Jennifer Jun-Li Chen, 2005). Then the authoritative parenting style significantly predicts academic performance (Turner, Chandler, \& Heffer, 2009).

To be able to give proper attention, parents must make time to interact with their children (S. P. Astuti \& Handayani, 2017). Parents have strong inner bonds with children. Emotional closeness, in addition to the emotional bond between parents and children, can also be formed through the attention of parents as early as possible. Whether we realize it or not, this emotional closeness can influence their child's psychological condition. If this closeness is not formed early on, it will be found by parents who do not know clearly about the child's development and what difficulties the child is facing.

If students are less close to their parents, it is a sign of the lack of family support for children's education. It should be noted that the support needed by children is not only in the form of fulfilling the necessary facilities, but also the child needs attention. Factors outside of students can influence the Interest, attention, and physical condition of students. If a student already has an interest and pays attention to a particular lesson, then a feeling will grow, which is called motivation to learn that moves students to improve their learning achievement. Intrinsic and extrinsic motivation correlates with academic performance (Ayub, 2010). The 
motivation that arises from within a person, especially the students consciously from within him, will be far better when compared to encouragement from others. Intrinsic motivation is related to academic success. Then motivation to learn contributes $48 \%$ to social studies learning outcomes (W. W. Astuti et al., 2012).

Previous researchers have succeeded in proving the direct influence of parents' socio-economic conditions, parental attention, and learning motivation on social studies learning achievement, and the effect of learning motivation on social studies learning achievement. The results of this research include the socio-economic conditions of parents proved to affect the performance of education (Considine \& Zappala, 2002; Prabawa, Dunia, \& Haris, 2014). One aspect that can describe the socioeconomic conditions is the level of income of different parents. Low parent's income will hamper the fulfillment of children's learning facilities (Rahayu, 2011). The results of subsequent research proved that learning motivation affects learning achievement (Mawarsih, Susilaningsih, \& Hamidi, 2013). If you want to improve your learning achievement, you will first increase your motivation to learn (Jen \& Yong, 2013; Mulyaningsih, 2014). Learning motivation acts as a predictor variable of learning achievement.

However, the mediating role of learning motivation on the influence of socioeconomic conditions, and the influence of parents' attention on learning achievement is still not sufficiently proven. For this reason, this study tries to prove whether learning motivation acts as a mediating variable.

\section{METHOD}

This research is a quantitative study that uses the ex post facto method and a questionnaire as a means of collecting data on parent's socio-economic conditions, parental attention, and motivation to learn. Whereas Social Studies learning achievement is obtained from the results of Social Studies teacher examinations in the even semester of the 2017/2018 Academic Year and at the same time as distributing research questionnaires to students. The questionnaire was first tested for reliability and reliability testing for 30 students outside the sample. The questionnaire was developed from the indicators of each variable. Questionnaires are first tested for validity and reliability testing for 30 students outside the sample. Questionnaires are developed from the indicators of each variable.

Table 1. The layout of the Questionnaire

\begin{tabular}{|c|c|c|}
\hline No & Variables & Indicators \\
\hline 1 & $\begin{array}{l}\text { Parental Socio- } \\
\text { Economic } \\
\text { Conditions }\left(\mathrm{X}_{1}\right)\end{array}$ & $\begin{array}{l}\text { a. Parent education } \\
\text { b. Neighborhood } \\
\text { c. Parent income level } \\
\text { d. Expenditures and } \\
\text { necessities of life }\end{array}$ \\
\hline 2 & $\begin{array}{c}\text { Parental } \\
\text { Attention }\left(\mathrm{X}_{2}\right)\end{array}$ & $\begin{array}{l}\text { a. Parents love } \\
\text { b. Providing guidance } \\
\text { c. Helping children } \\
\text { d. Creating a conducive } \\
\text { learning atmosphere }\end{array}$ \\
\hline 3 & $\begin{array}{l}\text { Motivation to } \\
\text { learn }\left(\mathrm{X}_{3}\right)\end{array}$ & $\begin{array}{l}\text { a. Desire and desire to } \\
\text { learn } \\
\text { b. Motivation to learn } \\
\text { c. Ideals / expectations } \\
\text { d. Award in learning } \\
\text { e. Interesting activities } \\
\text { f. A conducive } \\
\quad \text { environment }\end{array}$ \\
\hline 4 & $\begin{array}{c}\text { Learning } \\
\text { Achievement } \\
(\mathrm{Y}) \\
\end{array}$ & $\begin{array}{l}\text { Learning outcomes } \\
\text { from social studies } \\
\text { subject }\end{array}$ \\
\hline
\end{tabular}

(Uno, 2015)

The population in this study were all eighth-grade students of State Junior High School 35 Medan as many as 213 students; the sample was determined by the Slovin formula of 138 and taken proportionally from each class. Assumption tests including normality test, linearity test, heteroscedasticity test, and multicollinearity test. The data analysis technique used is path analysis, aiming to 
see the direct influence and indirect influence of the related variables. Test the hypothesis with the t-test (partial). The magnitude of the influence is directly seen from the Standardized Beta Coefficients.

The research structural equation is constructed as follows:

$X_{2}=P_{X_{2}} X_{1}+\varepsilon_{1}$

$X_{3}=P_{X_{3} X_{1}} X_{1}+P_{X_{3} X_{2}} X_{2}+\varepsilon_{2}$

$Y=P_{Y X_{1}} X_{1}+P_{Y X_{2}} X_{2}+P_{Y X_{3}} X_{3}+\varepsilon_{3}$

Modified from (Rochaety, Tresnati, \& Latief, 2009)

Explanation:

$\mathrm{X}_{1}=$ Parental Socio-Economic Conditions (PSEC)

$\mathrm{X}_{2}=$ Parental Attentions (PA)

$\mathrm{X}_{3}=$ Motivation to learn (MotL)

$\mathrm{Y}=$ Learning Achievement (LA)

$\varepsilon \quad=$ Residual

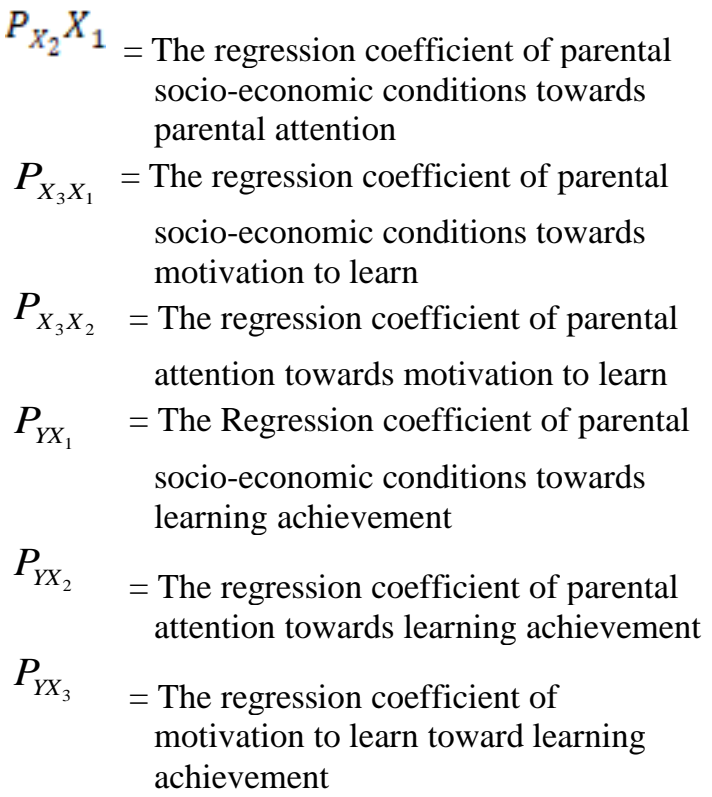

\section{RESULT AND DISCUSSION}

Based on the questionnaire, the overall sample condition can be seen in Table 2.

Table 2. Parental Socio-Economic Conditions and Parental Attention

\begin{tabular}{cccccccc}
\hline \multicolumn{2}{c}{ Parental Socio-Economic Conditions } & \multicolumn{4}{c}{ Parental Attention } \\
\hline Grade & $\mathbf{N}$ & Percentage & Category & Grade & N & Percentage & Category \\
\hline$>59$ & 30 & $21.74 \%$ & High & $>67$ & 28 & $20.28 \%$ & High \\
$50-59$ & 92 & $66.67 \%$ & Moderate & $59-67$ & 54 & $39.19 \%$ & Moderate \\
$<50$ & 16 & $11.59 \%$ & Low & $<59$ & 56 & $40.58 \%$ & Low \\
\hline Total & 138 & $100 \%$ & & Total & 138 & $100 \%$ & \\
\hline
\end{tabular}

The parental socio-economic conditions are generally moderate, while parental attention is mostly in the low category. Then, motivation to learn is mostly in the moderate category, while learning achievement generally is low, as presented in Table 3.

Table 3. Level of Student Motivation to Learn and Achievement

\begin{tabular}{cccccccc}
\hline & \multicolumn{3}{c}{ Motivation to Learn } & \multicolumn{4}{c}{ Learning Achievement } \\
\hline Grade & $\mathbf{N}$ & Percentage & Category & Grade & N & Percentage & Category \\
\hline$>75$ & 20 & $14.49 \%$ & High & $>79$ & 36 & $26.09 \%$ & High \\
$59-75$ & 84 & $60.87 \%$ & Moderate & $76-79$ & 46 & $33.33 \%$ & Moderate \\
$<59$ & 34 & $24.64 \%$ & Low & $<76$ & 56 & $40.58 \%$ & Low \\
\hline Total & 138 & $100 \%$ & & Total & 138 & $100 \%$ & \\
\hline
\end{tabular}

Based on the calculation, all data

are normally distributed and

homogeneous, as presented in Table 4. 
Table 4. Normality Test Results and Homogeneity Test

\begin{tabular}{lllccccc}
\hline & \multicolumn{1}{c}{ Variables } & \multicolumn{3}{c}{ Normality } & \multicolumn{3}{c}{ Homogeneity } \\
\cline { 3 - 8 } & & $\begin{array}{c}\text { Asymp. Sig. } \\
\text { (2-tailed) }\end{array}$ & Sig. & Explanation & $\begin{array}{c}\text { Levene } \\
\text { Statistik }\end{array}$ & Sig & Explanation \\
\hline 1. & $\begin{array}{l}\text { Parental Socio- } \\
\text { economic condition }\end{array}$ & 0.061 & 0.05 & Normal & 0.738 & 0.596 & Homogeneous \\
2. & $\begin{array}{l}\text { Parental Attention } \\
\text { 3. }\end{array}$ & 0.174 & 0.05 & Normal & 0.926 & 0.466 & Homogeneous \\
& $\begin{array}{l}\text { Motivation to } \\
\text { Learn }\end{array}$ & 0.174 & 0.05 & Normal & 0.409 & 0.842 & Homogeneous \\
4. & $\begin{array}{l}\text { Learning } \\
\text { Achievement }\end{array}$ & 0.158 & 0.05 & Normal & 0.469 & 0.799 & Homogeneous \\
\hline
\end{tabular}

The linearity test results show that all data are linearly related, as shown in Table 5.

Table 5. Summary of Linearity Test Results

\begin{tabular}{|c|c|c|c|c|}
\hline No & Variable & F Linearity & $\begin{array}{c}\text { F-Deviation } \\
\text { from Linearity }\end{array}$ & Explanation \\
\hline 1. & $P S E C \rightarrow L A$ & .000 & 1.000 & Linear \\
\hline 2. & $P S E C \rightarrow P A$ & .000 & 0.806 & Linier \\
\hline 3. & PSEC $\rightarrow$ MotL & .000 & 0.857 & Linier \\
\hline 4. & $P A \rightarrow$ Mot $L$ & .000 & 0.737 & Linier \\
\hline 5. & $P A \rightarrow L A$ & .000 & 0.918 & Linier \\
\hline 6. & MotL $\rightarrow L A$ & .000 & 0.222 & Linier \\
\hline $\begin{array}{l}\mathrm{D} \\
P \\
P \\
P \\
L\end{array}$ & $\begin{array}{ll}\text { cription: } & \\
& =\text { Parental S } \\
& =\text { Parental A } \\
& =\text { Motivatio } \\
& =\text { Learning }\end{array}$ & c Conditions & & \\
\hline
\end{tabular}

Heteroscedasticity test was done to test whether in the regression model variance of the residual inequality occurs one observation to the other observations. The variable parental socio-economic condition (PSEC) has a significance of 0.216 so that heteroscedasticity does not occur because it is more than 0.05 . Likewise, the variables of parental attention $(P A)$ with a significance of 0.397 and motivation to learn variables (MotL) with a significant 0.680 , both have significant values $>0.05$.

The multicollinearity test is intended to test whether in the formed regeneration model, there is a high or complete correlation between the independent variables or not. The variable parental socio-economic condition (PSEC) tolerance value is 0.849 , and VIF value is 1.177. Because the tolerance value is $>0.10$ and the VIF value is <
10.00 , there is no multicollinearity. Likewise, with the parental attention variable $(P A)$ with tolerance values $(0.711$ $>0.10)$ and VIF values $(1.406<10.00)$ and motivation to learn variables (MotL) with tolerance values $(0.681>0.10)$ and VIF values $(1,468<10.00)$.

This study uses 3 equations, namely structural equation 1,2 , and 3 . Structural equation 1 is $\mathrm{X}_{2}=0.315$ PSEC +0.949 , structural equation 2 is $\mathrm{X}_{3}=0.229 P S E C$ $+0.451 P A+0.824$, and structural equation 3 is $\mathrm{Y}=0.152 P S E C+0.402 P A$ +0.409 MotL +0.626 .

The results of the calculation of the effect of each variable positioned as exogenous variables on endogenous variables are presented in Figure 1. 


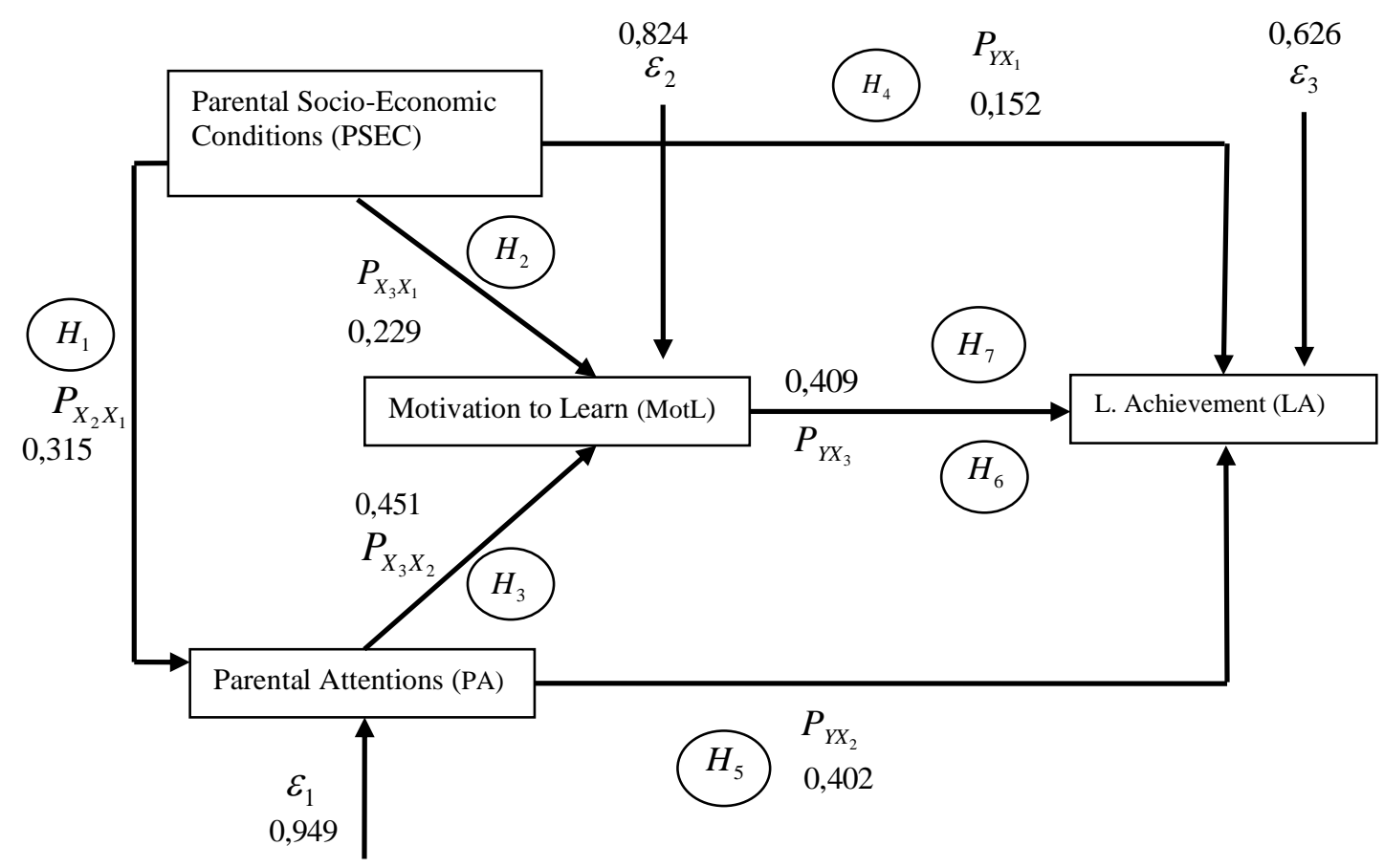

Figure 1. Path Analysis Result

Then the direct effects of variables and indirect effects are presented in Table 6.

Table 6. Path Coefficient

\begin{tabular}{|c|c|c|c|c|c|}
\hline \multirow[b]{2}{*}{ No. } & \multirow[b]{2}{*}{ Variables } & \multicolumn{4}{|c|}{ Effects } \\
\hline & & Direct & $\begin{array}{c}\text { Indirect through } \\
P A\end{array}$ & $\begin{array}{c}\text { Indirect through } \\
\text { MotL }\end{array}$ & Total \\
\hline 1 & $P S E C \rightarrow P A$ & 0.315 & & - & 0.315 \\
\hline 2 & PSEC $\rightarrow$ MotL & 0.229 & 0.142 & - & 0.371 \\
\hline 3 & $P A \rightarrow$ MotL & 0.451 & & - & 0.451 \\
\hline 4 & $P S E C \rightarrow L A$ & 0.152 & 0.127 & 0.094 & 0.373 \\
\hline 5 & $P A \rightarrow L A$ & 0.402 & & 0.184 & 0.586 \\
\hline 6 & MotL $\rightarrow L A$ & 0.409 & & - & 0.409 \\
\hline
\end{tabular}

Economic Conditions towards Parental Attention

The value of the path coefficient is 0.315 , and the significance value is 0.000 $<0.05$. This study proves that the socioeconomic conditions of father and mother directly and significantly influence the attention of both parents. This research reinforces previous research by (AlMatalka, 2014) where social status in the aspect of education is high, and they will have higher knowledge and understanding to guide children in the process of learning. Parents who have higher education will be able to guide their children in learning such as completing school assignments that are difficult to do. Also, parents can provide solutions to children's learning difficulties. Parents with well economic conditions are more natural to identify and help children complete homework and motivate children, provide the needs of the skills, tools, or instruments needed by their children. 
Furthermore, the well socioeconomic status of parents will also influence the continuing education of their children, while the cost of education is quite high (Haq \& Setiyani, 2016). Low socioeconomic status in terms of difficulties in the cost of education will disrupt the continuity of children's education. Better socio-economic conditions allow parents to pay attention to children more easily. Socio-economic conditions are closely related to education, living environment, and parents' income. Older people who have better education, of course, their insight into children's education, is also getting better. The social status is seen from the neighborhood, the family living in an elite environment or ordinary community environment will influence the condition of the child in learning more or less.

The size of parents' income will determine the level of parental care in meeting children's needs in learning. These three things determine the level of attention to children. The form of parental attention can be in the form of giving love, guidance, providing children's learning facilities, and creating a safe and comfortable learning environment for their children. Children who get attention, guidance from parents, and get a variety of better learning facilities are manifestations of better parents' attention too.

\section{Direct Effects of Parental Socio- Economic Conditions towards Students' Motivation to Learn}

Path coefficient value is 0.229 and the significance value is $0.003<0.05$. The variable parental socio-economic conditions have a positive and significant direct effect on motivation to learn. This study supports the results by (Djafar, 2014) that parents who have sufficient or high income, in general, will more easily meet all school needs and other needs, so that children will be motivated in learning. The high and low socio- economic class of parents influences motivation to learn (Kormos \& Kiddle, 2013). The motivation for learning can also be influenced by the needs of what is learned useful in life. People will learn foreign languages, for example, if the person in question requires English in his life. Students from families with higher socioeconomic backgrounds need English skills because most of them have contact with the English-speaking community both for travel and business, so they are more motivated to learn English (BektaúÇetinkayaa \& Oruçb, 2010).

The social condition of parents will have an impact on the child's mindset related to how the future he wants to achieve. The better the social condition of parents both in terms of education, socioeconomic, or living environment, will bring a good influence on children so that he is more motivated to learn to increase the target of his life to give pride to his parents.

\section{The Direct Effects of Parental Attention towards Students' Motivation to Learn}

Path coefficient value is 0.451 and the significance value is $0.00<0.05$. Then parental attention has a positive and significant direct effect on motivation to learn. This study also supports research results by (A'la, 2016; Iftikhah, 2004), that a good parent's attention at home will foster encouragement or good student motivation. Then, according to (Cheung \& Pomerantz, 2012), parental involvement in children's learning processes increases their value because it can foster motivation in children. Furthermore, (Rivers, Mullis, Fortner, \& Ronald, 2012) added that authoritative parenting showed more motivation to learn for children. The dominant and rigid parenting styles of their mothers also significantly correlated with motivation to learn (Rivers, Mullis, A, \& LnMullis, 2012). Then authoritative and authoritative care influences children's 
motivation to learn (Watabe, 2014). Moreover, parenting affects the motivation and academic behavior of children (Gonida \& Urdan, 2007). Students who have intelligence below the average, authoritative parenting style, and stiffness from the mother significantly correlate with learning motivation (Jankowska, Takagi, Bogdanowicz, \& Jonak, 2014).

To sustain and increase intrinsic motivation among students is needed the support of the home and school environment (Froiland, Oros, Smith, \& Hirchert, 2012). The home environment here is indeed inseparable from the role of older adults. Children in learning need praise; praise can be sourced from teachers at school and parents at home. Praise is a positive amplifier that has the potential to increase intrinsic motivation and extrinsic motivation (Froiland et al., 2012). Thus, the importance of praise needs to be encouraged to support enthusiastic how students develop towards academic or interpersonal mastery.

The attention given by parents can be in the form of fulfilling the needs of school fees and moral support. Students will think that their parents work hard and pay attention to the cost of education, so he must study well so as not to make his parents disappointed, so he diligently participates in school and study at home. Besides attention in the form of moral support such as attention to school assignments, difficulties experienced by students while studying in school, additional lessons needed outside of school and friends in the playing environment, also must be considered by parents to improve children's motivation to learn.

\section{Direct Effect of Parental Socio- Economic Conditions on Student Learning Achievement}

The value of path coefficient value is 0.152 , and the significance value is $0.011<0.05$. This study proves the socioeconomic conditions of parents directly influence social studies learning achievement. This finding is in line with the research by (Prabawa et al., 2014), where socio-economic parents play a role in improving student learning achievement. Therefore parents must be able to fulfill their children's daily learning needs (such as textbooks, exercise books, pens, pencils, and bags) to encourage their academic achievements (Ghazi, Ali, Shahzad, \& Hukamdad, 2014).

Children born to families with properly socio-economic status, usually all their learning needs will be fulfilled. While children born to families with underprivileged socioeconomic status are usually lacking in children's school needs. Because parents are more concerned with fulfilling basic daily needs. For this reason, financial assistance is needed for low-income families so that their children's academic achievements remain good.

The condition of socio-economic status has a different influence on the performance of education because of the different socio-economic conditions of the family (Considine \& Zappala, 2002). Low parent income will hinder the fulfillment of children's learning facilities (Rahayu, 2011).

\section{The Direct Effect of Parental Attention towards Students' Learning Achievement}

Path coefficient value is 0.402 and a significance value of $0.000<0.05$. This study proves that parents' attention has a positive and significant direct effect on learning outcomes. This research strengthens previous research that parents 
who have attention to their children will provide guidance and direction for children's learning activities so that children understand the importance of learning for their future. (Mawarsih et al., 2013; Prabawa et al., 2014). Parents usually care and always help their child's learning difficulties. The attention of parents plays an essential role in influencing learning achievement (Isnawati \& Setyorini, 2012). Students who get high attention from parents will be more hopeful for success in learning or achievement, but on the contrary, students who get low attention from their parents, the less hope for success in learning or achievement (Prabawa et al., 2014).

\section{Effect of Motivation to Learn on Students' Learning Achievement}

The value of path coefficient is 0.409 , and a significance value is $0.000<$ 0.05 . Motivation to learn is proven to have a positive and significant effect on social studies learning achievement. The results of this study are following what was done (Primaningtyas, 2013) that motivation to learn provides the most significant influence on social studies learning achievement. The motivation that students have encourages them to achieve learning achievement (Mawarsih et al., 2013). If students have motivation in learning, then their learning achievements will be excellent (high). Conversely, if students have bad habits in learning, then their learning achievements will be wrong (low) (Hamdu \& Agustina, 2011). Then achievement motivation also has a positive and significant effect on learning achievement, meaning that the higher the achievement motivation, the higher the learning achievement, so to improve learning achievement must begin with first increasing motivation (Jen \& Yong, 2013; Mulyaningsih, 2014). Previously, Atta \& Jamil, (2012) states that motivation is one of the capitals for a person to stay motivated to do something, including learning, to improve academic achievement (Atta \& Jamil, 2012). More they suggest parents and teachers can be asked to motivate students in the right way.

\section{The Effects of Mediation on Motivation to Learn and the Indirect Influence of Parental Attention on Learning Achievement}

Based on Table 6 , it can be seen that motivation to learn is proven to mediate (has an indirect effect) on the socioeconomic influence of parents on social studies learning achievement. The magnitude of the contribution of the motivation to learn the mediation variable is 0.094 . The presence of motivation to learn mediation can improve social studies learning achievement. However, the mediation of motivation to learn is more significant in the influence of people's attention on learning achievement by 0.184 . This condition is because the attention of parents is more in direct contact with the condition of the child's learning. Parents who always care about the difficulties of children learn more to encourage children to be more active learning than just providing learning facilities needed by children (socio-economic conditions).

The research results also proved a motivation to learn as a mediating variable on the influence of parents' socio-economic conditions on learning achievement (Steinmayr, Dinger, \& Spinath, 2012). The magnitude of the mediation of motivation to learn on the influence of parental attention to learning achievement also strengthened that parental attention also mediated (had an indirect effect) of 0.142 on the influence of socio-economic conditions on motivation to learn. The variable attention of parents also provides an indirect contribution of 0.127 on the influence of socio-economic conditions on social studies learning achievement. 


\section{CONCLUSION}

The parent's socio-economic condition has a positive and significant effect on parental attention. Then socioeconomic conditions and the attention of each parent have a direct positive and significant impact on motivation and learning achievement. Furthermore, learning motivation has a positive and significant effect on learning achievement. The variable of learning motivation is proven to mediate or have an indirect effect of 0.094 on the influence of parents' socio-economic conditions on learning achievement. However, more the mediating role of learning motivation on the influence of parental attention on achievement by 0.18 .

The direct influence of socioeconomic conditions and parental attention on learning achievement are 0.152 and 0.402 , respectively, higher than the mediating role of learning motivation (indirect effect) on the influence of socioeconomic conditions and parental attention on learning achievement, 0.094 and 0.184 respectively. To improve social studies learning achievements can be done by providing to meet all the learning needs of children and give more attention to children's learning at home because it will increase children's learning motivation and subsequently affect learning achievement.

\section{REFERENCES}

A'la, R. (2016). Perhatian Orang Tua Dan Motivasi Belajar Siswa. Jurnal Madaniyah, 2, 249-268.

Afiati, B., \& Kurniawan, R. Y. (2014). Pengaruh Status Sosial Ekonomi Orang Tua dan Kelompok Teman Sebaya terhadap Perilaku Konsumsi Siswa Kelas XI IPS MAN Sidoarjo. Jurnal Pendidikan Ekonomi (JUPE), 2(3), 1-7.

Ahmadi, A. (2005). Psikologi Perkembangan. Jakarta: Rineka
Cipta.

Al-Matalka, F. I. M. (2014). The Influence of Parental Socioeconomic Status on Their Involvement at Home. International Journal of Humanities and Social Science, 4(5), 146-154.

Astuti, S. P., \& Handayani, S. (2017). Pengaruh Perhatian Orang Tua dan Motivasi Berprestasi terhadap Prestasi Belajar Fisika. SAP (Susunan Artikel Pendidikan), 2(1), 1-11.

Astuti, W. W., FX, S., \& Partono, P. (2012). Pengaruh Motivasi Belajar dan Metode Pembelajaran terhadap Hasil Belajar IPS Terpadu Kelas VIII SMP PGRI 16 Brangsong Kabupaten Kendal. Economic Education Analysis Journal, 1(2), 16.

Atta, M. A., \& Jamil, A. (2012). Effects of motivation and parental influence on the educational attainments of students at secondary level. Academic Research International, 2(3), 427-431.

Ayub, N. (2010). Effect of Intrinsic and Extrinsic Motivation on Academic Performance. Pakistas Business Review, 363-372.

Bektaú-Çetinkayaa, Y., \& Oruçb, N. (2010). Turkish students` motivation to learn English at public and private universities. Procedia Social and Behavioral Sciences, 2, 4662-4666.

Cheung, C. S.-S., \& Pomerantz, E. M. (2012). Why Does Parents' Involvement Enhance Children's Achievement? The Role of ParentOriented Motivation. Journal of Educational Psychology, 103(3), 820-832.

Considine, G., \& Zappala, G. (2002). The influence of social and economic disadvantage in the academic performance of school students in Australia. Journal of Sociology, $38(2)$, 129-148. 
https://doi.org/10.1177/14407830212 8756543

Djafar, F. (2014). Pengaruh Kondisi Sosial Ekonomi Orangtua terhadap Motivasi Belajar Anak. Tadbir: Jurnal Manajemen Pendidikan Islam, 2(1), 1-13.

Djamarah, Bahri, S., \& Zain, A. (2010). Strategi belajar mengajar. Jakarta: Rineka Cipta.

DWP, S., \& Sulistyowati, H. (2006). Faktor-Faktor yang Mempengaruhi Kesulitan Belajar Mata Pelajaran IPS Ekonomi. Dinamika Pendidikan, 1(2), 162-181.

Froiland, J., Oros, E., Smith, L., \& Hirchert, T. (2012). Intrinsic motivation to learn: The nexus between psychological health and academic success. Contemporary School Psychology, 16(1), 91-100. https://doi.org/10.1016/00224405(83)90074-2

Ghazi, S. R., Ali, R., Shahzad, S., \& Hukamdad, H. (2014). Parental Involvement in Children Academic Motivation. Asian Social Science, 6(4). https://doi.org/10.5539/ass.v6n4p93

Gonida, E. N., \& Urdan, T. (2007). Parental influences on student motivation, affect and academic behaviour: Introduction to the Special Issue. European Journal of Psychology of Education, 22(1), 3-6. https://doi.org/10.1007/BF03173685

Hamdu, G., \& Agustina, L. (2011). Pengaruh motivasi belajar siswa terhadap prestasi belajar IPA di sekolah dasar. Jurnal Penelitian Pendidikan, 12(1), 90-96.

Haq, M. A., \& Setiyani, R. (2016). Pengaruh Prestasi Belajar, Kondisi Sosial Ekonomi Orang Tua Dan Self Efficacy Terhadap Minat Melanjutkan Studi Ke Perguruan Tinggi Siswa Ips. Economic Education Analysis Journal, 5(3), 1034-1045.

Iftikhah, R. (2004). Pengaruh Perhatian
Orang Tua Terhadap Motivasi Belajar Siswa. Ilmiah Pendidikan Bimbingan Dan Konseling, 85-93.

Isnawati, N., \& Setyorini, D. (2012).

Pengaruh Perhatian Orang Tua dan Motivasi Belajar terhadap Prestasi Belajar Akuntansi Pada Kompetensi Mengelola Dokumen Transaksi Siswa Kelas X Program Keahlian Akuntansi SMK Cokroaminoto 1 Banjarnegara TP 2011/2012. Jurnal Pendidikan Akuntansi Indonesia, $X(1), 27-47$.

Jankowska, A. M., Takagi, A., Bogdanowicz, M., \& Jonak, J. (2014). Parenting Style and Locus of Control, Motivation, and School Adaptation among Students with Borderline Intellectual Functioning. Current Issues in Personality Psychology, 2(4), 251-266.

Jen, C. S., \& Yong, B. C. S. (2013). Secondary School Students' Motivation and Achievement in Combined Science. US-China Education Review, 3(4), 213-228.

Jennifer Jun-Li Chen. (2005). Relation of Academic Support From Parents, Teachers, and Peers to Hong Kong Adolescents'Academic

Achievement: The Mediating Role of Academic Engagement. Genetic, Social, and General Psychology Monographs, 131(2), 77-127. https://doi.org/10.3200/MONO.131.2 $.77-127$

Kormos, J., \& Kiddle, T. (2013). The role of socio-economic factors in motivation to learn English as a foreign language: The case of Chile. System, 41(2), 399-412.

Maryani, E., \& Syamsudin, H. (2009). Pengembangan

Program Pembelajaran IPS Untuk Meningkatkan Kompetensi Keterampilan Sosial. Jurnal Penelitian, 9(1), 1-111.

Mawarsih, S. E., Susilaningsih, \& Hamidi, N. (2013). Pengaruh Perhatian Orang Tua dan Motivasi 
Belajar Terhadap Prestasi Belajar Siswa SMA Negeri Jumapolo. Jurnal Pendidikan Ekonomi (JUPE), 1(3), 1-13.

Mulyaningsih, I. E. (2014). Pengaruh Interaksi Sosial Keluarga, Motivasi Belajar, dan Kemandirian Belajar terhadap Prestasi Belajar. Jurnal Pendidikan Dan Kebudayaan, 20(4), 441-451.

Palupi, S. R., \& Djazari, M. (2017). Pengaruh Kemandirian Belajar, Persepsi tentang Metode Mengajar, Perhatian Orang Tua terhadap Prestasi Belajar Akuntansi. Kajian Pendidikan Akuntansi Indonesia, 2, 2-18.

Prabawa, K. A., Dunia, K., \& Haris, I. A. (2014). Pengaruh Sosial Ekonomi Dan Perhatian Orang Tua Terhadap Prestasi Belajar Ekonomi Siswa Kelas X4. Pengaruh Sosial Ekonomi Dan Perhatian Orang Tua (Vol. 4).

Primaningtyas, I. (2013). Pengaruh Kompetensi Guru dan Motivasi Belajar Siswa terhadap Prestasi Belajar Siswa Kelas VIII pada Mata Pelajaran IPS Terpadu SMP Negeri 6 Semarang Tahun 2012/ 2013. Economic Education Analysis Journal, 2(2), 144-151.

Rahardjo, S., \& Firdaus, M. R. (2015). Analisis Pengaruh Bauran Pemasaran, Status Sosial Ekonomi dan Motivasi Terhadap Keputusan Mahasiswa Dalam Memilih Kuliah (Studi Pada Lembaga Pendidikan dan Pengembangan Profesi Indonesia (LP3I) Business College Cabang Banjarmasin). Jurnal Wawasan Manajemen, 3(3), 45-60.

Rahayu, W. P. (2011). Analisis Intensitas Pendidikan oleh Orang Tua dalam Kegiatan Belajar Anak , Status Sosial Ekonomi Orang Tua terhadap Motivasi Belajar dan Prestasi Belajar Siswa. Jurnal Pendidikan Dan Pembelajaran, 18(1), 72-80.

Rakhmawati, I. (2015). Peran Keluarga dalam Pengasuhan anak. Jurnal Bimbingan Konseling Islam, 6(1), 118.

Rivers, J., Mullis, A. K., A, L., \& LnMullis, R. (2012). Relationships between parenting styles and the academic performance of adolescents. Journal of Family Social Work (Vol. 15). https://doi.org/10.1080/10522158.20 12.666644

Rivers, J., Mullis, A. K., Fortner, L. A., \& Ronald, L. (2012). Relationships Between Parenting Styles and the Academic Performance of Adolescents. Journal OfFamily Social Work, 15, 202-216. https://doi.org/10.1080/10522158.20 12.666644

Rochaety, E., Tresnati, R., \& Latief, H. A. M. (2009). Metodologi Penelitian Bisnis Dengan Aplikasi SPSS (Revisi). Jakarta: Mitra Wacana Media.

Steinmayr, R., Dinger, F. C., \& Spinath, B. (2012). Motivation as a Mediator of Social Disparities in Academic Achievement. European Journal of Personality, Eur. J, 26, 335-349. https://doi.org/10.1002/per

Turner, E. A., Chandler, M., \& Heffer, R. W. (2009). The Influence of Parenting Styles, Achievement Motivation, and Self-Efficacy on Academic Performance in College Students. Journal of College Student Development, 50(3), 337-346.

Umar, M. (2015). Peranan Orang Tua Dalam Peningkatan Prestasi Belajar Anak. Jurnal Ilmiah Edukasi, 1(1), 20-28.

Uno, H. (2015). Teori Motivasi dan Pengukurannya. Jakarta: Bumi Aksara.

Utami, P. S., \& Gafur, A. (2015). Pengaruh Metode Pembelajaran dan Gaya Belajar Siswa terhadap Hasil Belajar IPS di SMP Negeri di Kota Yogyakarta. Harmoni Sosial: Jurnal 
Pendidikan IPS, 2(1), 97-103.

Watabe, A. (2014). The Influence of Authoritarian and Authoritative Parenting on Children's Academic Achievement Motivation: A Comparison between the United States and Japan. North American Journal of Psychology, 16(2), 369382.

Yuliati, I. K. (2009). Penanaman sikap dan nilai pada pembelajaran IPS di sekolah dasar. Al-Bidayah, 1(2), 267-277. 